1) 総 SOD 活性は, 正常菌肉に比べ病変組織におい て全般的に低值を示した. Isozyme を検索すると病変 組織において CuZn-SOD の全般的な低下が認められた が，Mn-SOD の低下はさほど認められなかった。

2) Catalase は腫瘍性病変においてやや低值を示し, 囊胞性病変および炎症性病変において高值を示した。

3）GSH-Px は病変組織片全般において高値を示し 特に炎症性病変に扔いて高值を示した。

\section{4. 口腔領域悪性瘇塄患者における尿中ポリアミンの検} 討

\section{○津留 昭二・荒木 英隆・武富 晶子 末永 初広・黑川 英雄・梶山稔 (九歯大 $\cdot 2$ 口外)}

演者らは口腔領域悪性腫瘍患者の尿中ポリアミン値を 測定し, 腫煬マーカーとしての臨床的意義について検索 中であるが，乙れまでの測定成績を発表した。

対象症例は1987年 4 月から 1989年 4 月までの 2 年 1 か 月間䎲当科を受診した口腔癌患者 30 例（1 次症例 24 例， 2 次症例 6 例）で，同期間中の良性疾患患者20例を対照 例とした．また，尿中ポリアミンの測定は䤃素法により 行い, 以下の結果を得た。

1）口腔領域悪性腫湯患者の尿中ポリアミン值は，平 均值が $57.0 \pm 50.7 \mu \mathrm{mol} / \mathrm{g}$ クレアチニン $(\mathrm{n}=24)$ で, 良性疾患患者の $30.0 \pm 19.9 （ \mathrm{n}=20 ）$ と比べ有意汇高值 を示していた．また，陽性率は $58.3 \%$ (14/24例) で良 性疾患の $15.0 \%$ (3/20例）に比べて有意に高くなってい た。

2) 組織型では比較的例数の多い扁平上皮癌症例の平 均值が55.9 $\pm 54.3 \mu \mathrm{mol} / \mathrm{g}$ クレアチニン $(\mathrm{n}=20)$, 陽性 率は $50.0 \%$ (10/20例) であった。

3）臨床病期別では, 進行癌といわれる Stage III, Stage $\mathbb{N}$ では尿中ポリアミン值が比較的高值を示し， 陽性率も高くなっていた。

4） 1 次症例と 2 次症例在比較すると，尿中ポリアミ ン值，陽性率とも 1 次症例が高かったが，両者の間に大 きな差は認められなかった。

5 ）悪性腫瘍患者における切除前・後の尿中ポリアる ン值の変動をみると, 多くの症例では切除後に低下して いたが，術後に転移がみられた症例では再び高值を示し ていた。しかしながら，てれらの症例では病変の再切除 後には尿中ポリアミン值は速やかに低下していた。
6 ) 以上の結果からすれば，尿中ポリアミン值は口腔 癌の病期の進行度, 治療効果の判定, 再発の予知などに 有用な腫瘍マーカーとなりうるものと思われた。

\section{5. 口腔密に対する制密剤の局所注入療法の試み}

$$
\begin{aligned}
& \text { ○黒川 英雄・池田 浩 - 岡田 正明 } \\
& \text { 野村 俊夫・中村 貫司・杉本 忠雄 } \\
& \text { 林嘉仁・梶山馠 }
\end{aligned}
$$

(研究目的)

制癌剤の宿主に対する障害をできうるだけ回避し，よ り効果的な抗腫瘍効果を高める目的から，最近では制癌 剤以外の薬剤と併用する陚みが報告されている：ビスコ クラウリン型アルカロイドであるセファランチンは細胞 膜に作用し $\mathrm{Ca}^{+}$の透過性をもたらすといわれている. したがってその併用は癌細胞内への制癌剂の流入，流出 に関係し，投与量あるいは副作用を軽減し，加えて抗腫 瘍効果の増強が期待されるものと考え, 臨床的研究に着 手した。

(研究方法)

ペプロマイシン（日本化薬 KK 製，以下 PEP と略 す）とセファランチン（東京化生，以下 Ceph と略す） を予備実験として培養癌細胞 (KB 細胞) を用いて割合 比を検討したが， $1 ： 6$ の割合がより効果的であった。 すなわち PEP $5 \mathrm{mg}$ 亿対し Ceph 30mg 在混合し，癌 病巣の周囲から腫煬内へ向かって直接注入した。

（研究成績）

1. 投与回数および投与量：投与回数は最高 17 回, 最 低 1 回の平均 5.4 回であった。投与量は PEP が平均 $40.7 \mathrm{mg}$, Ceph が平均244.3mg で，すべて $1 ： 6$ の割 合で混合注入した。

2.治療経過および治療効果：癌病巣の表面は局注後 3〜 5 日で白色あるいは茶褐色の壊死状の白苔となる。 白苔は容易には豩離困難で，易出血性である．治療効果 では腫煌の完全消失・CR が 1 例, 腫場の $50 \%$ 以上の縮 小・PR が 3 例，腫場の $25 \sim 50 \%$ 縮小・MR が 2 例， 効果のみられない・NC が 1 例で，奏効率は $57.1 \%$ (4 / 7 例) であった。

3. 副作用：全症例とも諸種の臨床検査値に異常はな く，特に副作用はみられなかったが，腫瘍内注射時には 軽度の疼痛を訴えた。 